\title{
LIST OF PLATES
}

Plate 2.1 Cruise passengers are casual visitors at this nutmeg plantation in Grenada .............................................................................................. 22

Plate 2.2 Young Israeli students visiting Jerusalem's Old City .................................. 33

Plate 2.3 Heritage symbols of Juche doctrine dot the landscape of North Korea ... 34

Plate 2.4 Signs of natural seasonality on a heritage trail in New Brunswick, Canada

Plate 3.1 A popular opium museum in northern Thailand ........................................ 50

Plate 3.2 Minority cultural center/ethnic village in Yunnan Province, China ........ 52

Plate 3.3 Sydney Opera House, one of the world's iconic performance centers .... 53

Plate 3.4 Ancient pyramid at Tikal National Park, Guatemala ................................. 57

Plate 3.5 Bedouin tent for tourists in Israel ............................................................. 59

Plate 3.6 Aboriginal cultural performer in Queensland, Australia ............................ 60

Plate 3.7 Water Festival performed by the Dai people of Yunnan Province,

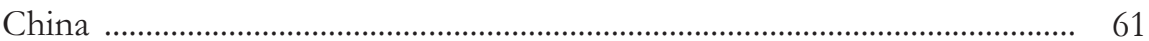

Plate 3.8 St Peter's Basilica, Vatican City, a major pilgrimage destination ............... 62

Plate 3.9 Mine tours on offer to tourists in southern Arizona, USA ....................... 63

Plate 3.10 Gettysburg National Military Park, Pennsylvania, USA ............................. 65

Plate 3.11 A political attraction in Buenos Aires, the Congress of the Argentine

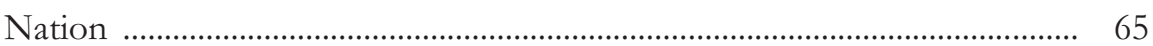

Plate 3.12 An important agro-heritage attraction is the Agrodome in New Zealand 67

Plate 3.13 The Hobbiton movie set, in New Zealand, is an example of literary

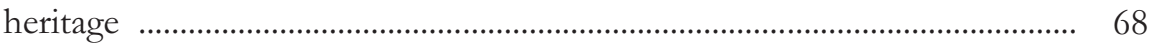

Plate 3.14 The Jesus Trail and trail marker near Nazareth .......................................... 69

Plate 3.15 Tourists riding the historic Kuranda Scenic Railway near Cairns, Australia .................................................................................................... 71

Plate 3.16 El Tovar historic lodge on the south rim of the Grand Canyon .............. 75

Plate 3.17 A four-star historic hotel in Colonia, Uruguay ........................................... 76

Plate 3.18 An antiquities shop in the Old City of Jerusalem ...................................... 77

Plate 4.1 An example of a global heritage site is the Roman Coliseum .................. 87

Plate 4.2 National heritage includes the Tomb of the Unknown Soldier, Arlington, USA 
Plate 4.3 This border marker between Dutch and French St Martin illustrates local heritage

Plate 4.4 This 'House of Names' in Ireland illustrates a personal heritage attraction 90

Plate 4.5 Tiny San Marino’s capital city with museums, churches and government buildings

Plate 4.6 Fascinating cultural landscape in rural Myanmar (Burma)

Plate 5.1 The Eiffel Tower in Las Vegas, an inauthentic reproduction 106

Plate 5.2 A traditional clog maker demonstrating his skills in the Netherlands ........ 110

Plate 5.3 These Native American pots are 'certified' authentic by their creators ..... 111

Plate 5.4 'Ozification' of Wamego, Kansas, one of several 'authentic' locations of $\mathrm{Oz}$

Plate 5.5 Actors at the Kalevu Cultural Centre re-enact a kava ceremony in Fiji .... 117

Plate 5.6 Modern devices, such as this fire hydrant, in Colonial Williamsburg, draw criticism from some cultural observers

Plate 6.1 A recently-constructed slave cabin at Mount Vernon, Virginia, helps portray a more accurate version of history

Plate 6.2 An opium propaganda museum in Mongla, Myanmar (Burma) 138

Plate 6.3 The destroyed Mostar Bridge (a UNESCO site) in Bosnia before its reconstruction

Plate 6.4 This destroyed mosque near Medjugorje, Bosnia Herzegovina, is a casualty of the mid-1990s Yugoslavian wars

Plate 7.1 This medieval pilgrim graffiti has become a permanent part of a sacred site in the Holy Land

Plate 7.2 Large crowds of tourists waiting to enter the Vatican Museums

Plate 7.3 Indian teepee being commodified in Arizona, where teepees never originally existed

Plate 7.4 Tourists rubbing the feet of St Peter in the Vatican City

Plate 7.5 Caves in Aruba where ancient Arawak Indian paintings were destroyed by tourist vandals

Plate 7.6 Ritual litter in the Ganges River, India, creates health and esthetic problems

Plate 8.1 Instructional sign to help conservation efforts in a national park in Australia

Plate 8.2 A commemorative marker in Saint John, New Brunswick, erected by Canada's Historic Sites and Monuments Board

Plate 8.3 San Juan National Historic Site (US National Park Service), one of Puerto Rico's most significant cultural attractions 
Plate 8.4 A MERCOSUR-funded renovation project at Jesuit Missions World Heritage Site, Paraguay

Plate 8.5 UNESCO marker in Nepal, a country that strongly values its World Heritage Sites 188

Plate 9.1 Archaeological digs at Historic Jamestowne, USA, provide information about American colonial life

Plate 9.2 Batalha Monastery, Portugal, is an example of Late Gothic architecture worth preserving

Plate 9.3 The Taj Mahal is among the most valued historic buildings for its esthetic design

Plate 9.4 This 1880s hospital in Fredericksburg, Texas, is now a tourist shop and restaurant

Plate 9.5 Efforts to retard deterioration at Paquimé (Casas Grandes) World Heritage Site, Mexico

Plate 9.6 Example of a medieval house in the Netherlands with visible renovations

Plate 9.7 Vianden Castle, Luxembourg, was restored from ruins to its 14th century form in the 1970 s

Plate 9.8 Darling Harbor, Sydney, Australia, exemplifies waterfront redevelopment for tourism and recreation

Plate 9.9 The Old City of Jerusalem suffers severe pressures from masses of tourists

Plate 9.10 New roofs in Dubrovnik have replaced many of those destroyed in the mid-1990s Yugoslavian wars

Plate 9.11 Christ the Redeemer statue (Brazil) undergoing reinforcement and cleaning to mitigate the effects of erosion

Plate 10.1 Elementary school field trip to Harper's Ferry National Historical Park, USA

Plate 10.2 A Benjamin Franklin re-enactor lends humor to a visit to historic Philadelphia

Plate 10.3 Signage to help direct tourists away from a sensitive historic artifact ...... 237

Plate 10.4 A guide interprets the past for tourists at Casa Grande Ruins National Monument, USA

Plate 10.5 Actors at Mount Vernon (George Washington's home) demonstrate historic crafts

Plate 10.6 This placard tells the story of Mission Espada, part of 'Texas' Spanish colonial heritage

Plate 10.7 This scale model of the Vatican City helps tourists appreciate the layout of the tiny microstate 
Plate 10.8 This interpretive display invites visitors to touch and handle cultural artifacts

Plate 10.9 This vendor is renting multilingual self-guided audio tours of the Alamo in Texas

Plate 10.10 This young visitor utilizes interactive, computer-based interpretation at an archaeological site

Plate 10.11 Non-English speaking tourists visiting Bingham Canyon Copper Mine, USA, can hear the story in several languages

Plate 10.12 Many interpretive signs in Israel are printed in the country's two official languages, Hebrew and Arabic, as well as in English

Plate 10.13 This native Guarani guide at Iguazu Falls, Argentina, contributes to the indigenous narrative of the region's heritage

Plate 11.1 This pedestrian zone in Warsaw, Poland, contributes to the city's historic ambience

Plate 11.2 Reflecting public-private cooperation, at this highway rest stop, public services are provided by private businesses

Plate 11.3 This billboard in Nicosia, Cyprus, illustrates the desire of both parts of the island to collaborate for heritage planning

Plate 12.1 For some tourists, these iconic views of Venice epitomize the city and the romanticism of Italy

Plate 12.2 The Hobbiton movie set is part of the Lord of the Rings appeal of New Zealand

Plate 12.3 Authenticity of Native American art is important in marketing indigenous heritage

Plate 13.1 Admission prices for foreigners at this museum in Bhutan are ten times higher than for Bhutanese

Plate 13.2 A typical donation box at a heritage site .................................................. 300

Plate 13.3 A museum store at the Smithsonian, Washington, DC 301

Plate 13.4 Formal souvenir vendors at Lumbini, Nepal, the birthplace of Buddha

Plate 13.5 This cafe sells Native American traditional food at the National Museum of the American Indian in Washington, DC

Plate 13.6 Extra income is earned at the ruins of Caesarea, Israel, by hosting a wedding reception

Plate 13.7 Railings keep tourists from touching ancient Native American petroglyphs

Plate 13.8 Ancient artifacts in a museum covered to prevent contact with visitors 
Plate 13.9 This trail through a heritage landscape in New Brunswick, Canada, is well 'hardened'

Plate 14.1 A local fort museum in Khasab, Oman

Plate 14.2 This archaeological museum in Thessaloniki houses artifacts from all over northern Greece

Plate 14.3 This tiny brick border museum lies just a few inches inside the Netherlands and is popular among border enthusiasts

Plate 14.4 The Smithsonian's National Museum of the American Indian is an important attraction in Washington, DC

Plate 14.5 This small mining museum attracts few tourists but is part of the outback landscape of Australia

Plate 15.1 This ancient amphitheater in Caesarea, Israel, doubles as a venue for modern performances

Plate 15.2 Volunteer archaeologists catalogue colonial-era glass shards in Philadelphia, USA

Plate 15.3 This overgrown ruin at Tikal, Guatemala, has yet to be excavated 345

Plate 15.4 The temple of Bacchus in Baalbek, Lebanon, is one of the best preserved Roman temples in the world

Plate 16.1 Neuschwanstein Castle in Germany is one of the country's most recognizable elitist icons

Plate 16.2 The Capitol Building in Washington, DC, is an important symbol of the American nation

Plate 16.3 This castle in Northern Ireland can be rented for special events and exemplifies the elitist heritage of the British Isles

Plate 16.4 These colorful rice terraces in southern China are an important tourist attraction

Plate 16.5 This farmland scene adds to Austria's cultural appeal 357

Plate 16.6 These grain elevators in Manitoba, Canada, are important symbols of the prairie agricultural heritage

Plate 16.7 This village in Bhutan forms part of an appealing cultural landscape in the Himalayas

Plate 16.8 This native Australian demonstrates traditional 'bush tucker' to tourists at an aboriginal cultural center

Plate 16.9 Wine routes link viticulture heritage sites together in British Columbia, Canada

Plate 17.1 The US Mint is an important industrial attraction in Philadelphia 371

Plate 17.2 This crafter in Denmark demonstrates the ancient glass-making industry 
Plate 17.3 Itaipu Dam on the border of Paraguay and Brazil draws visitors interested in its construction and energy-generation functions

Plate 17.4 The Kennecott Copper Mine is an 'anchor' attraction near Salt Lake City

Plate 17.5 This cheese factory lends supporting appeal to the area of Bern, Switzerland

Plate 17.6 This ghost town is all that remains of a 19th century mining operation in the western USA

Plate 18.1 This small church in Aruba is one of the island's main cultural attractions

Plate 18.2 The location of Buddha's birthplace in Nepal draws many visitors each year

Plate 18.3 Kushinagar, India, is known as the place where Buddha died and is one of Buddhism's holiest sites

Plate 18.4 Local worshippers and tourists alike pray at the Western Wall in Jerusalem

Plate 18.5 The Dome of the Rock in Jerusalem is one of Islam's holiest sites ...... 393

Plate 18.6 Among many protestant Christians, the Garden Tomb in Jerusalem is thought to be the burial chamber of Jesus

Plate 18.7 Christian tourists at the ruins of the synagogue of Capernaum

Plate 18.8 The ritual bath in the Ganges at Varanasi, India, is an important part of Hindu religious heritage

Plate 18.9 Catholic pilgrims, retracing the footsteps of Jesus with a cross in Jerusalem

Plate 18.10 A reminder for tourists to respect local religious traditions and sacred space

Plate 19.1 Roots tourists often visit and gather information from old cemeteries such as this one in England

Plate 19.2 Genealogy libraries and heritage centers are an important part of the experience of roots tourists

Plate 19.3 Clan burial grounds such as this one in Scotland are important attractions for personal heritage tourists

Plate 19.4 A Birthright Israel bus waits for Jewish-American youth tourists near Tel Aviv

Plate 19.5 Sydney, Australia's Chinatown is popular for locals and tourists for its dining and shopping

Plate 19.6 The Amish landscape of Pennsylvania shows the group's rejection of most modern conveniences 
Plate 20.1 These Panama natives are a salient part of the cultural product 425

Plate 20.2 This Maori cultural center in Rotorua is a popular stop on New Zealand tours

Plate 20.3 Copycat indigenous crafts are sold at this tourist shop in Mexico 431

Plate 20.4 The Karen people of Myanmar (Burma) have little control over their role in tourism

Plate 20.5 Emiratis performing a modified traditional camel dance in a shopping mall in Dubai

Plate 21.1 The Topaz Japanese internment camp in Utah lies in ruins 450

Plate 21.2 Remnants of the penal colony of Norfolk Island 451

Plate 21.3 Ruins of a sugar plantation in French Saint Martin is a testimony of Caribbean slavery

Plate 21.4 Site of the westernmost battle of the US Civil War in Arizona ................ 456

Plate 21.5 Israel's security wall separating Jerusalem from Bethlehem 458

Plate 21.6 The spot where Yitzhak Rabin was assassinated in Tel Aviv is a popular attraction for Israelis

Plate 21.7 The hallowed grounds of Arlington National Cemetery enliven the patriotic spirit of American tourists

Plate 21.8 Fans of Eva Peron adorn her Buenos Aires tomb daily with flowers and messages of admiration 
